\title{
ANALYSIS OF THE EFFECTS OF CO2 EMISSIONS FROM COAL-FIRED POWER PLANTS ON THE GROSS DOMESTIC REGIONAL PRODUCT IN JAKARTA
}

\author{
Arry Rahmawan Destyanto ${ }^{1}$, Akhmad Hidayatno $^{1 *}$, Adinda Amalia ${ }^{1}$ \\ ${ }^{1}$ System Engineering, Modeling, and Simulation Laboratory, Department of Industrial Engineering, \\ Faculty of Engineering, Universitas Indonesia, Kampus UI Depok, Depok 16424, Indonesia
}

(Received: April 2017 / Revised: May 2017 / Accepted: November 2017)

\begin{abstract}
The phenomenon of rapid economic growth has caused a rise in energy consumption in Jakarta, including a rise in the need for electricity. To supply the population's needs, Perusahaan Listrik Negara (PLN), Indonesia's state-owned electricity company has a plan to build an additional power plant; the energy industry in Indonesia is currently dominated by coal-based power plants. However, this mega project will have an impact on Jakarta's economy (gross domestic regional product, GDRP) and the $\mathrm{CO}_{2}$ emissions will have an effect as a result of the social cost of carbon because the coal-fired power plant has the highest emission rate compared with other power-plant types. Through the system-dynamics (SD) approach, this study aimed to examine several alternative policy scenarios and determine the best options that can be applied by the Jakarta government to ensure the success of electricity production, which can help to grow Jakarta's economy and minimize the effects of $\mathrm{CO}_{2}$ emissions simultaneously. Three policies were simulated in the model: business as usual (BAU), a green policy, and a good economic policy. The results of simulation show that each scenario has its own advantages and disadvantages to achieve government target. This study reveals that using combination of green and economic policy is highly recommended to help Jakarta's growth sustainably.
\end{abstract}

Keywords: Electricity; Gross domestic regional product; Social cost of carbon; System dynamics

\section{INTRODUCTION}

Indonesia is the country with the fourth biggest population in the world, with a total population of 247 million (Ho, 2014). The potential of this significant population drives economic growth, which is an average $5.4 \%$ per year $(\mathrm{Ho}, 2014)$. Moreover, Indonesia is predicted to become the country with the seventh biggest economy in the world by 2030 (Oberman et al., 2012). Jakarta, as the capital city of Indonesia, has become the city that has the highest population density in the world. The total population of Jakarta has reached 10,177 million people, which is 15,366 people $/ \mathrm{km}^{2}$ in terms of population density (Rochadiyat et al., 2016). Furthermore, Jakarta's population growth is the fastest among other cities in Indonesia, with a growth rate of $3.11 \%$ per year, and is also faster than Indonesia's national population growth, which is $1.37 \%$ per year (Rochadiyat et al., 2016). The significant potential of the population and the rapid expansion of urbanization has allowed Jakarta's economy to contribute $16 \%$ to national economic output in Indonesia, and it has the highest income per capita in Indonesia of approximately US\$7,600 according to the Central Bureau of Statistics (BPS, 2015).

\footnotetext{
*Corresponding author's email: akhmad@eng.ui.ac.id, Tel: +62-21-78888805, Fax: +62-21-78885656

Permalink/DOI: https://doi.org/10.14716/ijtech.v8i7.783
} 
This rapid economic growth is obviously related to energy consumption, which includes electricity as one of the energy sources. According to Bhattacharyya (2011), energy is one of the most important factors for running a city or country, particularly for developing a city like Jakarta. This is backed up by the statement from Erahman et al. (2016) that electricity takes an important place, running everything from people's daily activities to industrial operations. As the capital city of Indonesia, electricity demand in Jakarta is high and is continuously increasing each year. The peak load that has been recorded on the electricity system in Jakarta province (not including Kepulauan Seribu) was around 4,615 MW in August 2015. The power plant capacity that circuit with a $150 \mathrm{kV}$ grid is around 3,690 MW; this is from two different locations: PLTGU/PLTU Muara Karang and PLTGU/PLTG Tanjung Priok (Kementerian Energi dan Sumber Daya Mineral, ESDM; Perusahaan Listrik Negara, PLN, 2016). From 2016 to 2025, Jakarta will be building some additional power plants; these are $100 \mathrm{MW}$ PLTGU Senayan in 2017, 500 MW PLTGU Muara Karang in 2017, 800 MW PLTU Jawa 2 in 2018, and 1000 MW Jawa 12 in 2022/2023 (ESDM; PLN, 2016). In this plan, the coal-fired power plant will predominantly be used at PLTU/PLTGU. According to ESDM (2016), coal is a fuel that creates the largest volume of greenhouse-gas (GHG) emissions compared to others. One of GHG substance which takes the greatest part is carbon dioxide or $\mathrm{CO}_{2}$ (Suresh et al., 2010) .

According to Grossman and Krueger (1994, cited in Alam et al., 2016), there is an indirect correlation between economic growth and environmental degeneration, including air pollution. This is corroborated by Lean and Smyth (2010), who find a long-term association between electricity consumption and emissions in Association of Southeast Asian Nations (ASEAN) countries, one of which is Indonesia. Moreover Adamantiades and Kessides (2009), DeCanio (2009), Reddy et al. (2009), and Hu et al. (2011) all indicate in their previous studies that if a region does not pay attention to the emissions problem, which is closely related to global warming, the region will experience not only an environmental degeneration but also an economic loss. According to Chae and Park (2011), the way emissions affect the economy can be measured using the social cost of carbon (SCOC). The definition of the social cost of carbon is the net present value of the effects of global warming (such as decreased agricultural production, health dangers, or flood risk) in approximately 100 years, from one ton of $\mathrm{CO}_{2}$ being emitted in today's atmosphere. SCOC can be used as a standard to assure positive economic growth while keeping environmental sustainability as a challenge the government must face (Berawi, 2016).

To restrain environmental degeneration, most of the developed countries in the world have already applied the concept of sustainable development. This is defined as development that can fulfill the generation's needs and that pays attention to the next generation's ability to meet their needs (United Nations General Assembly, 1987). Sustainable development is a wider concept that not only maintains the environment but also takes into consideration the economic, social, and sustained environment balance (Chen et al., 2006).

Therefore, this study aims to answer a question from the set of policy plans that can be made by the Jakarta government, as part of the government's effort to simultaneously create a successful electricity development plan, grow the economy, and minimize the effects of $\mathrm{CO}_{2}$ emissions effect, alongside generating sustainable development.

\section{METHODOLOGY}

The dynamics among energy production capacity, energy consumption level, and environmental sustainability has a unique and complex relationship. Scientists have previously concluded that positive economic growth will degenerate environmental sustainability 
(Meadows et al., 1972). The relationship between energy consumption and environmental sustainability will become more complicated, and several scientists find the relationship itself is nonlinear (Grossman \& Krueger, 1995). In addition to facing nonlinearity in this relationship, it is also argued that the inverted U-shaped graph developed by Kuznets (1955) can be used to describe the relationship between energy consumption and the degeneration of environmental sustainability. The nonlinearity factor and many other variables involved in the relationship can increase the level of uncertainty for policy makers, who want to intervene in the system to achieve sustainable development (Hidayatno et al., 2015). A similar complexity has occurred for the interconnection between energy consumption and environmental sustainability degeneration as a result of the development of the coal-fired power-plant program in Jakarta. This is not only because coal-fired power plants can directly increase $\mathrm{CO}_{2}$ emissions but this also raises the energy consumption.

Over the few past decades, many scientists have tried to formulate a methodology for solving such kinds of problem, which involve high levels of uncertainty because of their variability and the dynamics of the interdependencies among variables. Many researchers have limited their research to using existing methods, such as statistics and econometrics. Bankes (1992) argues that using a simulation methodology can provide more advantages and relevant insights for a long period of time because simulation can include a time dynamics factor in the system. Previous research shows promising results from applying system dynamics (SD) to analyze policies or complex systems because SD can describe the whole structure and actual behavior of the systems (Forrester, 1994; Sterman, 2000). The precise development of an SD model could lead to various leveraging variables that dominantly affect the overall system (Barlas, 2002; Feng et al., 2013). A research project by Hidayatno et al. (2011) uses SD model is for analyzing sustainability in the palm-based biodiesel production chain.

This paper focuses on a discussion about how the government can intervene, through several policy alternatives, to achieve the necessary goals for sustainable development, especially for the installation program for new coal-fired power plants, while keeping environmental sustainability in Special Capital Region (Daerah Khusus Ibukota, DKI) Jakarta using the SD methodology. In more detail, the methodology in this study used SD modeling on electricity production, the macro economy, and the $\mathrm{CO}_{2}$ emission rate in Jakarta. This methodology consists of four steps; these are model conceptualization, model formulation, verification and validation, and scenario analysis, which is as described by Rodríguez-Ulloa et al. (2004).

\subsection{Model Conceptualization}

In this stage, the first process was creating a causal loop diagram to describe the interconnection among the included variables and performing an interrelationship analysis among the affected factors. Furthermore, at this stage the requirements for data to develop the system and visualization from the causality diagram that will show the behavior over time were developed. In this research, the Threshold 21 (T21) model is used as the base framework to develop the SD model. The Millennium Institute developed the T21 model as an integrated development model based on SD. The T21 model is designed to support a comprehensive and integrated development plan. The model structure was developed based on the sustainable development concept, which covers the economic, social, and environmental aspects. However, in this study, the electricity aspect is included as one of the economic growth drivers and environmental degeneration triggers. The causal loop diagram in this study is shown in Figure 1.

Furthermore, the model conceptualization will defines the model variables, which consist of endogenous variables, exogenous variables, and excluded variables. The endogenous and exogenous variables are divided into three different modules, (economic, electricity, and socioenvironmental) and are measured through various output indicators, which are gross domestic 
regional product (GDRP), SCOC, and amount of electricity production.

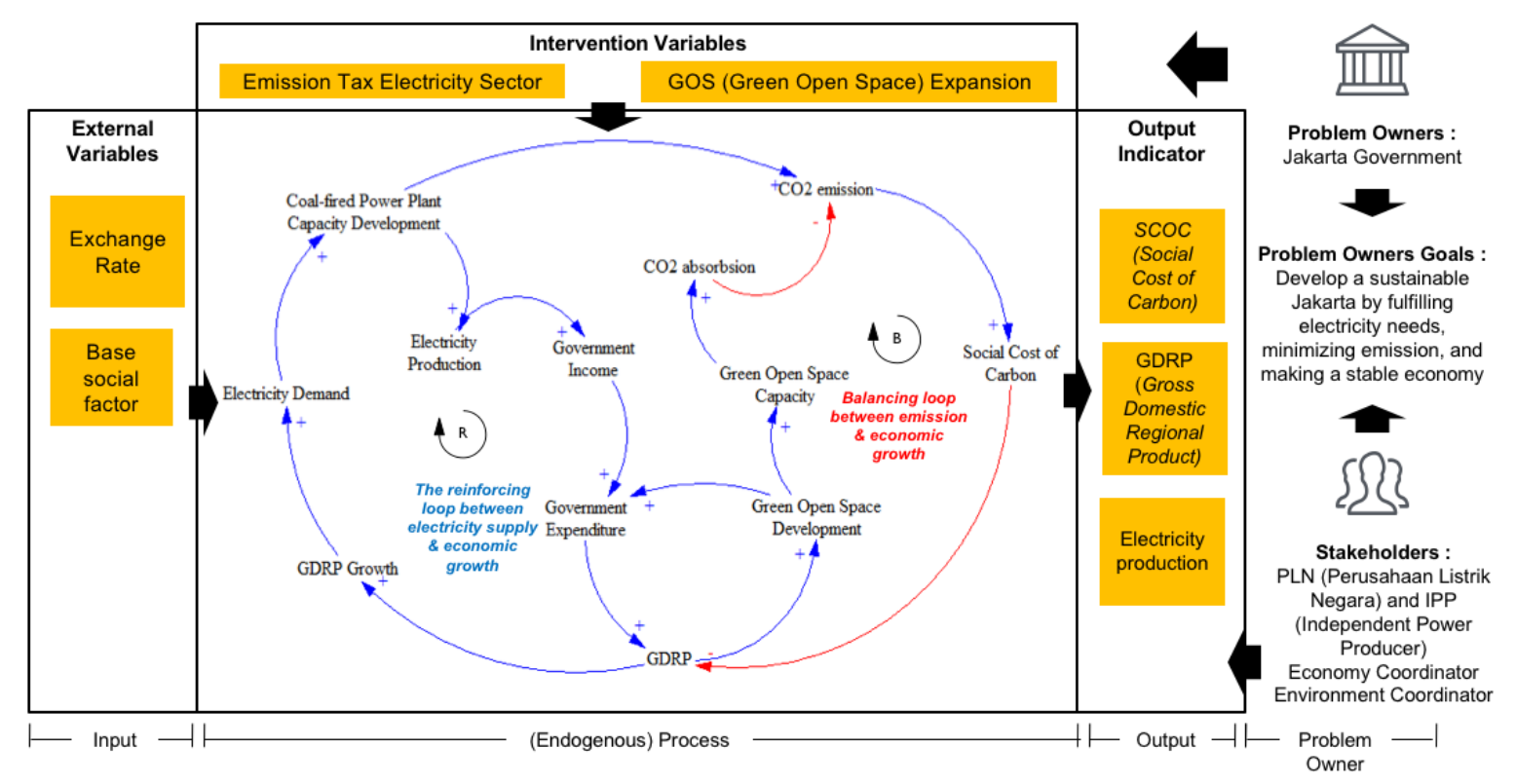

Figure 1 System diagram describing model conceptualization

\subsection{Model Formulation}

In this stage, the process is to formulate the variables that are used (in stocks, flows, converters, etc.) and develop the stock and flow diagram (SFD). Moreover, the model is drawn up using computer simulation software based on the previously developed causal loop diagram. The computer simulation software used to establish this model in this research was Powersim Studio. This SFD consists of three base modules, which are the economic module, electricity module, and socio-environmental module. The socio-environmental module also consists of three sub-modules: the emissions module, population module, and green open space (GOS) module. The bird's eye view of the finished SFD in Powersim Studio is given in Figures 2, 3, and 4.

\subsubsection{Electricity module}

The electricity module shows the calculation of total electricity production in Jakarta, where its value is the main output indicator for this module. In this module, there is one stock described as the installed power-plant capacity. This capacity will increase during the time frame of power-plant development in Jakarta from 2016 to 2025 and will decrease along with the depreciation of power plant itself. It is assumed that this power plant will produce the planned capacity of electricity and this is converted into the total amount of electricity production in Jakarta. From the other side, electricity demand is triggered by an increase in economic growth, summarized in the GDRP. Based on the amount of electricity demand and production in Jakarta, the discrepancy between electricity supply and demand is determined, which is known as the electricity gap. If an electricity shortage happens in this nine-year time frame (2016 to 2025) and the profitability of coal-fired power plants in Jakarta shows a positive value, the Jakarta government will build the additional PLTU Jawa-12 1000 MW in 2025.

\subsubsection{Economic module}

In the economic module, GDRP consumption at a constant price takes the role of the output indicator. GDRP is counted as an aggregate value for the GDRP initially expected in 2025. In this module, GDRP increases alongside the natural economic growth for Jakarta, based on the 
PLN report in the Electricity Supply Plan (Rencana Umum Penyediaan Tenaga Listrik, RUPTL) for 2016 to 2025. Moreover, the GDRP will decrease annually, alongside the growth of $\mathrm{CO}_{2}$ emissions, as a result of the monetary value of the SCOC that accumulates annually. On the other hand, government consumption will be triggered by government income, which is prompted by electricity production, through tax. Based on the production function concept, the higher electricity production will drive an increase in Jakarta's production in several sectors such as the services, manufacturing, and agriculture sector. A direct implication of increases in the production sector is growth in government income from tax in those business sectors.

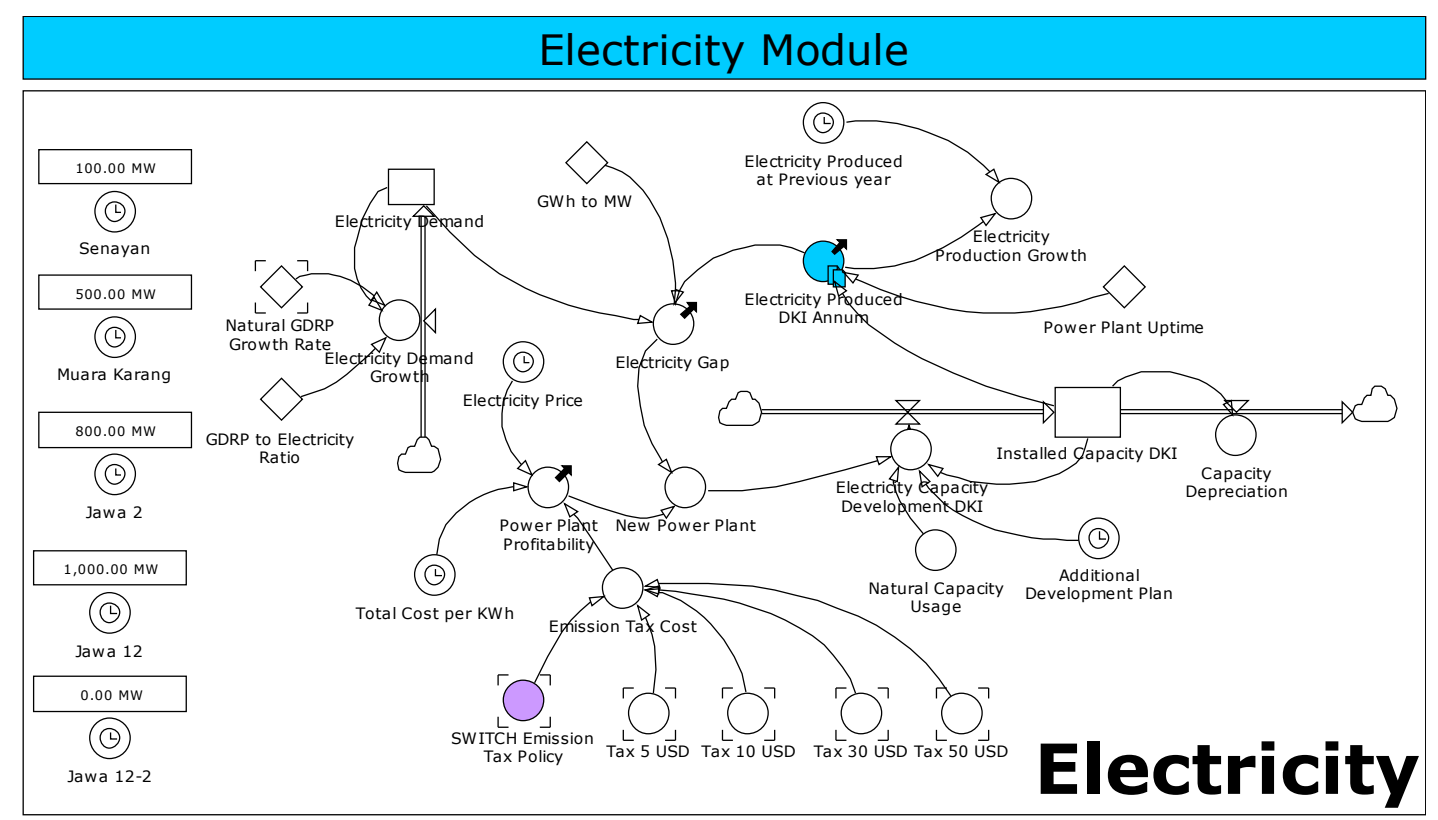

Figure 2 The bird's eye view of stock and flow diagram for electricity module

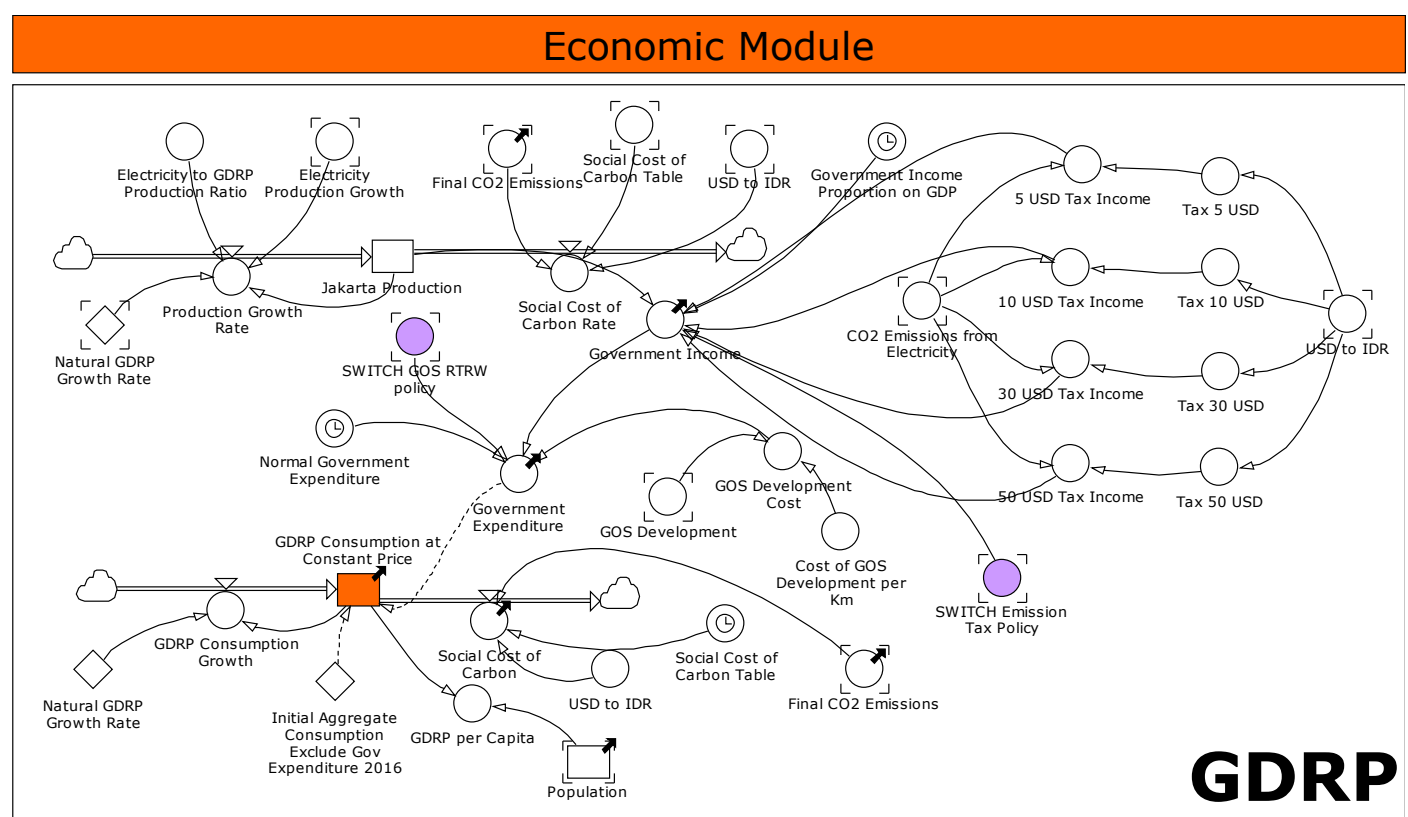

Figure 3 The bird's eye view of stock and flow diagram for economic module

\subsubsection{Socio-Environmental Module}

The socio-environmental module consists of three sub-modules, which are $\mathrm{CO}_{2}$ emissions, population, and GOS sub-module. In the $\mathrm{CO}_{2}$ emissions sub-module, there are two main 
sources of emissions: petroleum-based emissions and natural-gas emissions. Petroleum-based emissions are defined as accumulated emissions from petroleum used by residents, transportation, industries, and power plants. In this module, other non- $\mathrm{CO}_{2}$ types of $\mathrm{GHG}$ are considered to be equivalent to $\mathrm{CO}_{2}$, and GOS absorption will reduce total emissions. In addition, the population sub-module consists of one stock that represents the total size of the population in Jakarta. The inflow of this stock is the annual birth rate, and the outflow is the annual mortality and migration rates. The last one is the GOS sub-module which also consists of one stock that is calculated based on how much GOS area has been developed in Jakarta. The inflow of this sub-module is the reclamation rate or GOS development every year. GOS is assumed to be one of the effective ways to absorb $\mathrm{CO}_{2}$ emissions. Therefore, the total area of GOS is multiplied by the emission-absorption rate in ton $/ \mathrm{km}^{2}$, and, from this calculation, we obtain the total volume of $\mathrm{CO}_{2}$ emissions after it has been reduced by GOS absorption.
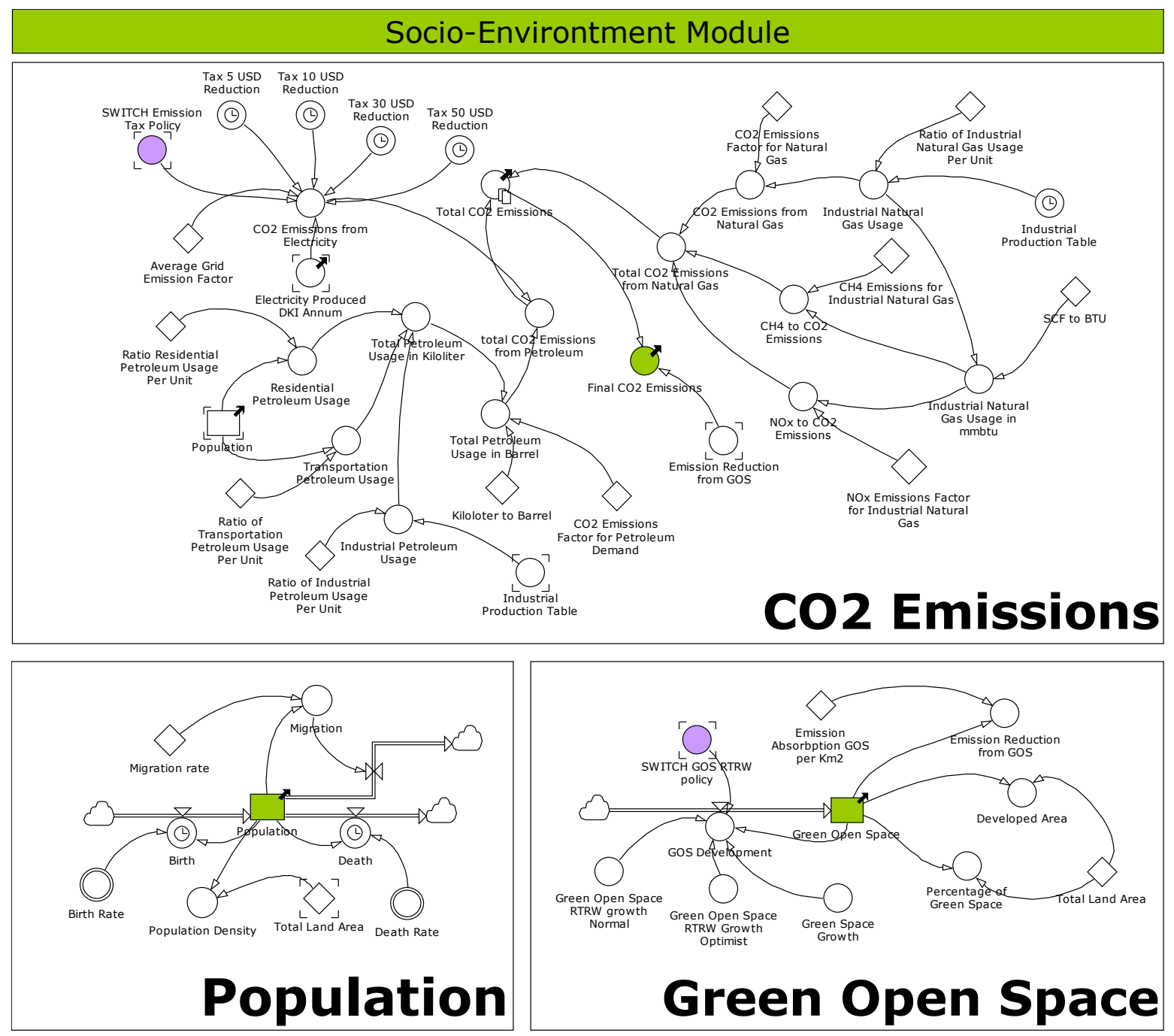

Figure 4 The bird's eye view of stock and flow diagram for socio-environment module

\subsection{Verification and Validation}

In this step, a verification process is completed to verify the equation, parameters, and boundaries of the model. This verification is done using Powersim Studio software, in which the model could be run correctly. No undefined variables are found. Furthermore, the model validation uses several methods to make sure the model's behavior is similar to real-world behavior. One of the techniques used is a behavior comparison using a reference mode 
(Sterman, 2000). This method tries to compare historical data with the model indicator output. This study obtained historical and forecast future behavior data from the appropriate institutions, such as PLN and the BPS. Two output indicators are validated, the electricity production rate and the GDRP of Jakarta. When the model was tested in this validation stage, it showed similar behavior to the reference model, and there is no significant difference between the model and reference model's behavior. The behavior comparison of the two indicators is illustrated in Figure 5.
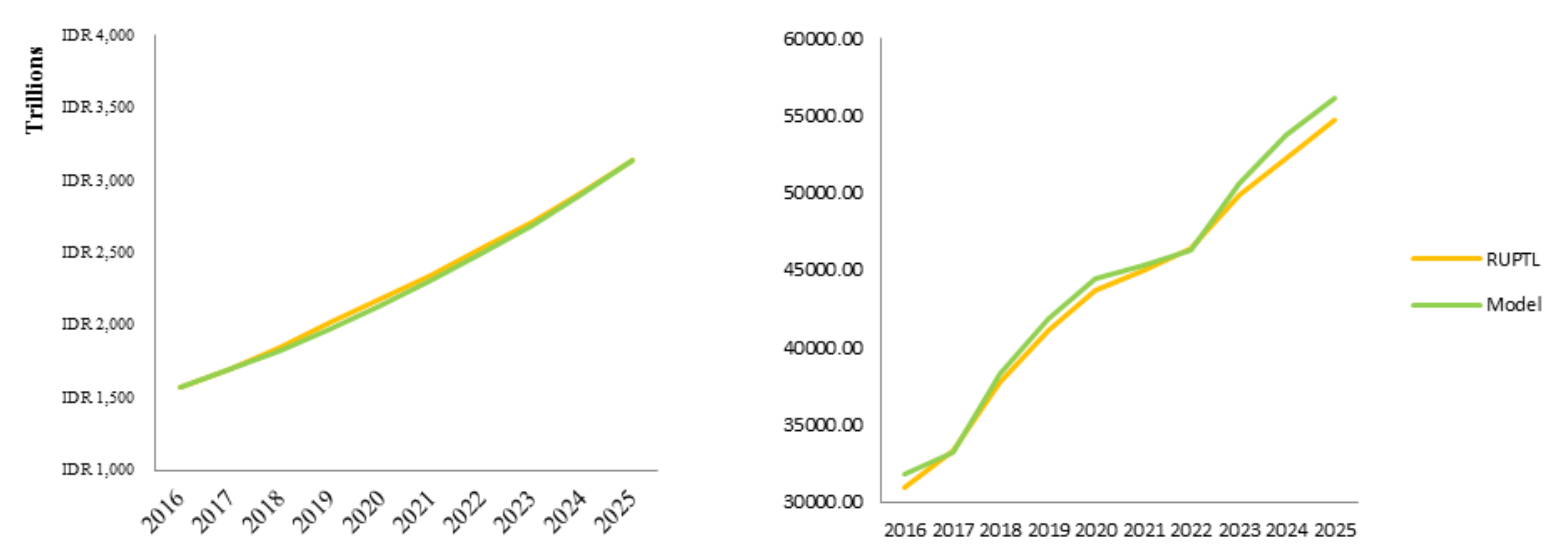

Figure 5 Comparison of model indicator output, GDRP $(l e f t)$, and electricity supply (right) with the reference model

\subsection{Scenario Analysis}

After the SD model has been verified and validated, the next step is to conduct an experiment or test of an alternative policy (also called a scenario) that can be applied to obtain an acceptable result, based on three aspects: electricity production, economic growth, and total emissions. There are three scenarios tested in this model: business as usual (BAU), a green policy, and a good economic policy. From these three scenarios, there are also two intervention variables: GOS and emissions tax. The parameter values for the intervention variables in each scenario are shown in Table 1.

Table 1 Variable parameter settings for each scenario

\begin{tabular}{lcc}
\hline \multicolumn{1}{c}{ Scenario } & Green Open Space (GOS) Expansion & Emissions Tax in Electricity Sector \\
\hline $\begin{array}{l}\text { Business as usual } \\
\text { BAU })\end{array}$ & $5.5 \mathrm{~km}^{2}$ per year & $0 \mathrm{US} \$$ per ton $\mathrm{CO}_{2}$ \\
\hline $\begin{array}{l}(16 \% \mathrm{GOS} \text { in } 2025) \\
\text { Green policy }\end{array}$ & $\begin{array}{l}\left(1.25 \mathrm{~km}^{2} \text { per year }\right. \\
(25 \% \mathrm{GOS} \text { in } 2025)\end{array}$ & $10 \mathrm{US} \$$ per ton $\mathrm{CO}_{2}$ \\
$\begin{array}{l}\text { Good economic } \\
\text { policy }\end{array}$ & $\begin{array}{c}5.5 \mathrm{~km}^{2} \text { per year } \\
(16 \% \mathrm{GOS} \text { in } 2025)\end{array}$ & $10 \mathrm{US} \$$ per ton $\mathrm{CO}_{2}$ \\
\hline
\end{tabular}

\section{RESULTS AND DISCUSSION}

The results of the simulation for the three scenarios are compared by using the output indicators described in the system diagram; these are the GDRP of Jakarta, the SCOC, and electricity production. For the GDRP indicator, the results for the three scenarios show that the goodeconomic-policy scenario creates the highest nominal value of GDRP, which is IDR 1,500 billion in 2016 with it continuously increasing to become IDR 3,000 billion in 2025. This happens because, in this scenario, there is no additional funding to develop additional GOS and 
there is a big additional income from emissions tax in the electricity sector. This is slightly different from the green-policy scenario, where the government should provide extra funding to build additional GOS space to reduce the emissions. However, when comparing the economic growth in each scenario, the green-policy scenario creates a compound annual growth rate (CAGR) of approximately $7.52 \%$, for the good-economic-policy scenario this is $7.51 \%$, and it is $7.49 \%$ from BAU in 2025 . It also shows that in the green-policy scenario, the economy will grow $0.01 \%$ faster than the good- economic-policy scenario and $0.03 \%$ faster than BAU. The result for each scenario is illustrated in Figure 6.

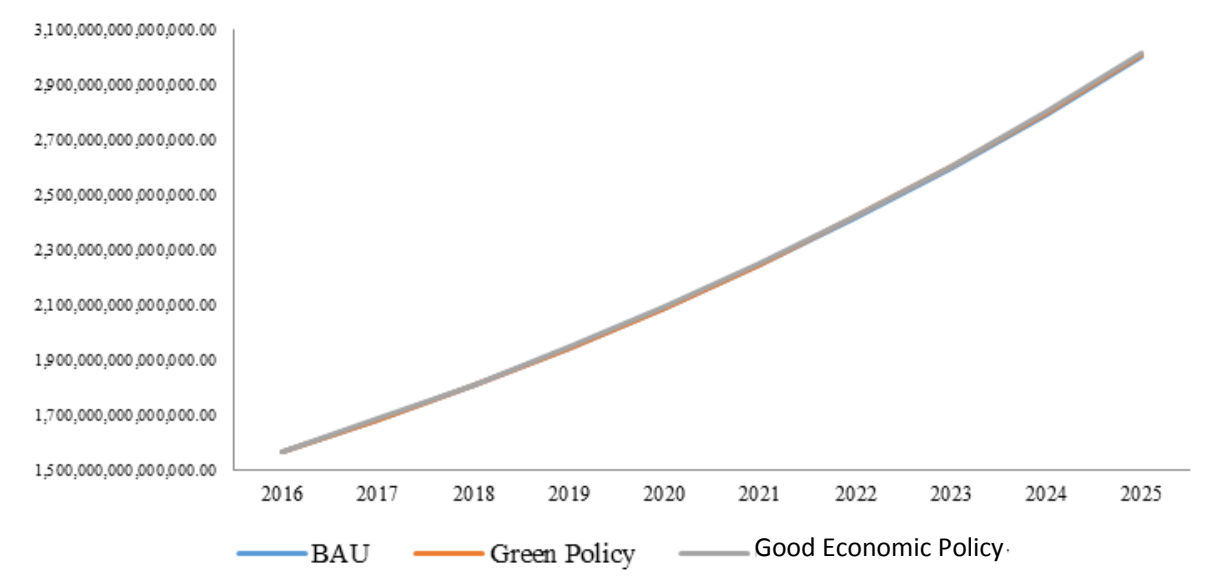

Figure 6 Behavior over time of the GDRP indicator tested in three different scenarios

Based on the graph above, there is no significant behavioral change within scenarios. This is because, according to the Intergovernmental Panel on Climate Change (2014), the decreasing and increasing values of emissions will not change the behavior or pattern of the economy until that region reaches the diminishing point. However, the result for the SCOC indicator shows that the green-policy scenario has the lowest value of SCOC compared with the others. This result gives an indirect indication that the green-policy scenario also creates the lowest emissions rate. Furthermore, the green-policy scenario also has the lowest growth of emissions, which shows that the government may be able to reach the 2030 target. The green-policy scenario creates a CAGR of $3.20 \%$, the good-economic-policy scenario creates a CAGR of $3.46 \%$, and BAU creates a CAGR of $3.20 \%$.

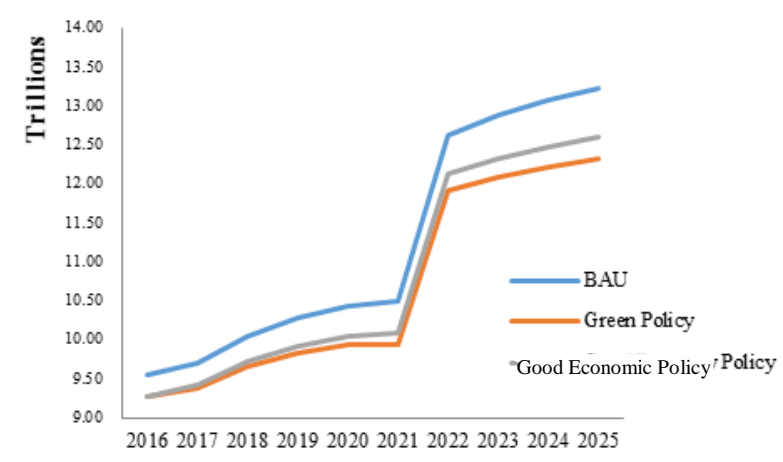

Figure 7 Behavior over time of the SCOC indicator tested in three different scenarios

The behavior over time graph in Figure 7 shows that there is no change regarding behavior but there is in value. This graph also indicates that the SCOC value will generally increase from 2016 to 2021. However, in 2022, because of increasing SCOC per ton of carbon from US\$5 to 
US\$6, the total value of SCOC will rapidly increase in this year. According to the Intergovernmental Panel on Climate Change (2014), the value of SCOC in a particular country will increase once in 5 to 10 years, and the value itself will be different in the various countries.

For the model's last indicator (electricity production), there is no change with respect to value or behavior for all scenarios. This is because even though there is a cost increase from the additional cost of emissions, the profitability still shows a positive value in all scenarios.

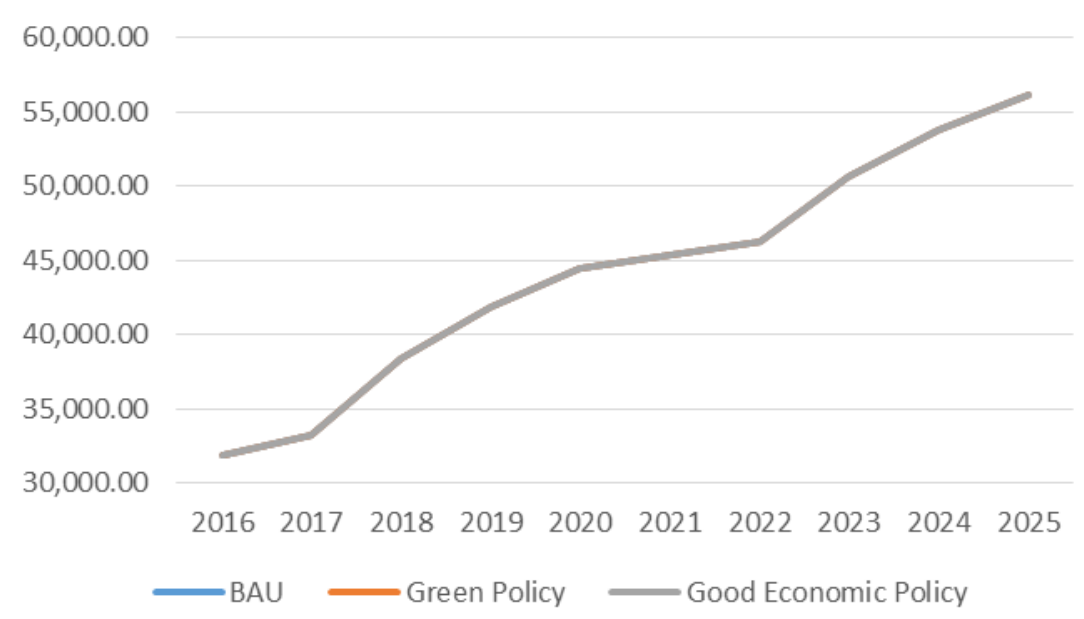

Figure 8 Behavior over time of the electricity production indicator tested in three different scenarios

The result also shows that power-plant profitability will continuously increase and shape the linear graph in all three scenarios. This is because the plan for the electricity price for nine years ahead is still higher due to the power-plant operational costs, one of which is the price of the coal used as fuel.

After testing three different scenarios, it is clear that all of them have different points of strength and weakness. For the GDRP indicator, the good-economic-policy scenario gives the highest value of GDRP, but the green-policy scenario reveals the maximum growth of GDRP. However, for the SCOC indicator, the green-policy scenario creates the lowest cost, and shows the lowest total emissions in Jakarta. The last indicator, electricity production, has no change in the value for production because power-plant productivity in Jakarta still shows a positive value from 2016 to 2025.

Even though a good economic policy will create the highest value of GDRP, the green-policy scenario gives the highest economic growth compared to the others, which is $0.01 \%$ greater than for the good-economic-policy scenario and $0.03 \%$ higher than the BAU scenario. The Jakarta government can apply and combine the two scenarios, by using the good-economicpolicy scenario for the first couple of years to boost GDRP, then continue by implementing the green-policy scenario to reduce the emissions in Jakarta.

\section{CONCLUSION}

In this study, three major points can be concluded. The first conclusion is that, in the electricity module, Jakarta will not experience an electricity shortage within the period from 2016 to 2025 because the volume of production still showed a higher value than electricity demand. However, the results of the simulation also revealed an electricity demand growth that is higher than production, which indicates that an electricity shortage may happen after 2025. Furthermore, Jakarta's economy will see average CAGR growth that is $7.49 \%$ higher than Indonesia's economic growth. The emissions rate in Jakarta also will grow continuously with a 
CAGR of $1.61 \%$, so that this, along with the increase in emissions, will create harmful effects that are measured in the SCOC.

The second conclusion is that these three scenarios have different points of strength and weakness. For the GDRP indicator, the good-economic-policy scenario indicated the highest value for it, but the green-policy scenario revealed the maximum growth of GDRP. However, for the SCOC indicator, the green-policy scenario will create the lowest cost, which demonstrated the scenario that gives the lowest total emissions in Jakarta. The last indicator, electricity production, had no change in the production value because power-plant productivity in Jakarta still showed positive values for the period from 2016 to 2025 . Even though a good economic policy will create the highest value of GDRP, the green-policy scenario will give the highest economic growth compared to the others, which is $0.01 \%$ higher than the goodeconomic-policy scenario and $0.03 \%$ higher than the BAU scenario.

Based on the results of this research, we suggest that the Jakarta government should apply and combine two of the scenarios, using the good-economic-policy scenario for the first couple of years to boost GDRP, then continue by implementing the green-policy scenario to reduce Jakarta's $\mathrm{CO}_{2}$ emissions.

\section{REFERENCES}

Adamantiades, A., Kessides, I., 2009. Nuclear Power for Sustainable Development: Current Status and Future Prospects. Energy Policy, Volume 37(12), pp. 5149-66

Alam, M., Murad, W., Hanifa, A., Ozturk, I., 2016. Relationships among Carbon Emissions, Economic Growth, Energy Consumption and Population Growth: Testing Environmental Kuznets Curve Hypothesis for Brazil, China, India, and Indonesia. Ecological Indicators, Volume 70, pp. 466-479

Bhattacharyya, S., 2011. Energy Economics: Concepts, Issues, Markets and Governance. $1^{\text {st }}$ ed. Springer-Verlag London

Bankes, S.C., 1992. Exploratory Modeling and the Use of Simulation for Policy Analysis. A RAND Note

Barlas, Y., 2002. System Dynamics: Systemic Feedback Modeling for Policy Analysis. Knowledge for Sustainable Development: An Insight into the Encyclopedia of Life Support Systems, pp. 1131-1175

Berawi, M.A., 2016. Accelerating Sustainable Infrastructure Development: Assuring Wellbeing and Ensuring Environmental Sustainability. International Journal of Technology, Volume 7(4), pp. 527-529

Chae, Y., Park, J., 2011. Quantifying Costs and Benefits of Integrated Environmental Strategies of Air Quality Management and Greenhouse Gas Reduction in the Seoul Metropolitan Area. Energy Policy, Volume 39(9), pp. 5296-5308

Intergovernmental Panel on Climate Change, 2014. Integrated Risk and Uncertainty Assessment of Climate Change Response Policies. Climate Change 2014, Mitigation of Climate Change, pp. 151-206

Chen, S., Kuo, H., Chen, C.C., 2007. The Relationship between GDP and Electricity Consumption in 10 Asian Countries, Volume 35(4), pp. 2611-2621

DeCanio, S.J., 2009. The Political Economy of Global Carbon Emissions Reductions. Ecological Economics, Volume 68(3), pp. 915-924

ESDM, 2016. Handbook of Energy and Economic Statistics of Indonesia

ESDM, PLN, 2016. PLN's Electricity Business Plan 2016-2025 (Rancangan Usaha Penyediaan Tenaga Listrik PLN 2016-2025). (in Bahasa)

Erahman, Q.F., Q., Purwanto, W.W., Sudibandriyo, M., Hidayatno, A., 2016. An Assessment of Indonesia's Energy Security Index and Comparison with Seventy Countries. Energy, 
Volume 111, pp. 364-376

Feng, Y.Y., Chen, S.Q., Zhang, L.X., 2013. System Dynamics Modeling for Urban Energy Consumption and $\mathrm{CO}_{2}$ Emissions: A Case Study of Beijing, China. Ecological Modelling, Volume 252, pp. 44-52

Forrester, J.W., 1994. Systems Dynamics, Systems Thinking, and Soft OR. System Dynamics Review, Volume 10(2-3), pp. 245-256

Grossman, G.M., Krueger, A.B., 1995. Economic Growth and the Environment. JSOTR, Volume 110(2), pp. 353-377

Hidayatno, A., Rahman, I., Muliadi, R., 2015. Policy Analysis of the Jakarta Carbon Mitigation Plan using System Dynamics to Support Decision Making in Urban Development - Options for Policymakers. International Journal of Technology, Volume 5(8), pp. 886-893

Hidayatno, A., Sutrisno, A., Zagloel, Y.M., Purwanto, W.W., 2011. System Dynamics Sustainability Model of Palm-oil Based Biodiesel Production Chain in Indonesia. International Journal of Engineering \& Technology, Volume 1(3), pp. 1-6

Hu, Z., Yuan, J., Hu, Z., 2011. Study on China's Low Carbon Development in an Economy Energy - Electricity - Environment Framework. Energy Policy, Volume 39(5), pp. 25962605

Ho, E., 2014. Deloitte Consumer Insight Intercepting consumer behaviour shifts in Indonesia (rep.), Deloitte Consumer Insight Intercepting consumer behaviour shifts in Indonesia. Deloitte South East Asia Ltd.

Kuznets, S., 1955. Economic Growth and Income Inequality. The American Economic Review, Volume 45(1), pp. 1-28

Lean, H.H., Smyth, R., 2010. $\mathrm{CO}_{2}$ Emissions, Electricity Consumption and Output in ASEAN. Applied Energy, Volume 87(6), pp. 1858-1864

Meadows, D.H., Meadows, D.L., Randers, J., Behrens III. W.W., 1972. The Limits to Growth a Report for the Club of Romes Project on the Predicament of Mankind. Universe Books

Millennium Institute, 2000. Threshold 21 (T21) Overview. USA: Millennium Institute

Oberman, R., Dobbs, R., Budiman, A., Thompson, F., Rosse, M., 2012. The Archipelago Economy: Unleashing Indonesia's potential. McKinsey Global Institute. Jakarta: McKinsey \& Company

Reddy, B.S., Assenza, G.B., Assenza, D., Hasselmann, F., 2009. Energy Effeciency and Climate Change: Conserving Power for a Sustainable Future. SAGE Publications India Pvt Ltd

Rochadiyat, Y., Pudyaswati., Apsari, R., Gunawan, W. (Ed.)., 2016. Jakarta Dalam Angka 2016. Jakarta, Indonesia: BPS Provinsi DKI Jakarta

Rodríguez-Ulloa, R.A, Paucar-Caceres, A., Kennedy, M., Winch, G.W., Langer, R.S., Rowe, J.I., Yanni, J.M., 2004. Soft System Dynamics Methodology (SSDM) : A Combination of Soft Systems Methodology and System Dynamics. In: Proceedings of the $22^{\text {nd }}$ International Conference of the System Dynamics Society, pp. 1-36

Sterman, J., 2000. Business Dynamics: System Thinking and Modeling for a Complex World. Boston: The McGraw Hill Companies, Inc

Suresh, M.V.J.J., Reddy, K.S., Kolar, A.K., 2010. Energy for Sustainable Development 4-E (Energy , Exergy , Environment, and Economic) Analysis of Solar Thermal Aided Coalfired Power Plants. Energy for Sustainable Development, Volume 14(4), pp. 267-279

United Nations General Assembly, 1987. Report of the World Commission on Environment and Development: Our Common Future. Oslo, Norway: United Nations General Assembly, Development and International Co-operation: Environment 